\title{
Words matter: a call for humanizing and respectful language to describe people who experience incarceration
}

\author{
Nguyen Toan Tran ${ }^{1,2^{*}}$ (D) Stéphanie Baggio ${ }^{1}$, Angela Dawson ${ }^{2}$, Éamonn O'Moore ${ }^{3}$, Brie Williams ${ }^{4}$, Precious Bedell ${ }^{5}$, \\ Olivier Simon ${ }^{6}$, Willem Scholten ${ }^{7}$, Laurent Getaz ${ }^{1}$ and Hans Wolff ${ }^{1}$
}

\begin{abstract}
Background: Words matter when describing people involved in the criminal justice system because language can have a significant impact upon health, wellbeing, and access to health information and services. However, terminology used in policies, programs, and research publications is often derogatory, stigmatizing, and dehumanizing.

Discussion: In response, health experts from Europe, the United States, and Australia recommend that healthcare professionals, researchers, and policy makers working with people in detention follow key principles that foster constructive and humanizing language. These principles include: engage people and respect their preferences; use stigma-free and accurate language; prioritize individuals over their characteristics; and cultivate self-awareness. The article offers examples of problematic terms to be avoided because they do not convey respect for incarcerated people and propose preferred wording which requires contextualization to local language, culture, and environment.

Conclusion: The use of respectful and appropriate language is a cornerstone of reducing harm and suffering when working with people involved in the criminal justice system; the use of stigmatizing and dehumanizing language must therefore come to an end.
\end{abstract}

Keywords: Health in prisons, Incarceration, Terminology, Access, Stigma, Discrimination, Harm reduction, Human rights

\section{Background}

Worldwide more than ten million people are held in penal institutions [1]. People who are incarcerated have greater physical and mental health needs than the general population [2] and can experience considerable stigma and discrimination that impact upon their access to health services [3]. To achieve health equity, this priority population needs adequately-resourced health services that are at least equivalent to those offered in the community [4]. Furthermore, increased research on health in prison is required to improve our understanding of factors that influence the health and wellbeing of incarcerated people so that health interventions best meet their needs [5]. Importantly, they must be engaged

\footnotetext{
* Correspondence: nguyen-toan.tran@hcuge.ch

${ }^{1}$ Division of Prison Health, Geneva University Hospitals and University of Geneva, Ch. du Petit-Bel-Air 2, CH-1225 Chêne-Bourg, Switzerland

${ }^{2}$ Australian Centre for Public and Population Health Research, Faculty of Health, University of Technology, PO Box 123, Sydney, NSW 2007, Australia Full list of author information is available at the end of the article
}

in the design and implementation of such services to ensure non-judgemental and stigma-free care.

Stigma can be enacted and reinforced through labelling. Such labelling can drive the stereotyping, prejudice, and discrimination of groups of people, such as individuals involved in the criminal justice system who are often denounced as being responsible for their incarceration. As a result, those in the criminal justice system are excluded from social and economic resources and services that ultimately affect their health and wellbeing [6]. Therefore, language used to describe individuals and populations, either respectful or stigmatizing, matters and shapes people's views and understanding of past and present events, as well as future possibilities [7]. Individuals affected by the criminal justice system face multiple stigma as they may be arrested and incarcerated for their use of psychoactive substances, HIV status, mental health conditions, sexual orientation or behaviours, or irregular migratory situation [8]. Stereotyping can be

(c) The Author(s). 2018 Open Access This article is distributed under the terms of the Creative Commons Attribution 4.0 International License (http://creativecommons.org/licenses/by/4.0/), which permits unrestricted use, distribution, and reproduction in any medium, provided you give appropriate credit to the original author(s) and the source, provide a link to the Creative Commons license, and indicate if changes were made. The Creative Commons Public Domain Dedication waiver (http://creativecommons.org/publicdomain/zero/1.0/) applies to the data made available in this article, unless otherwise stated. 
engrained in cultural norms and values and in structures and systems, so much so that negative effects on marginalized groups may no longer be noticed, becoming part of routine behaviour. Such stigma and discrimination can affect the identities of incarcerated individuals, how they see themselves (from perceived stigma to internalized stigma [9]), and how society perceives 'them'. Language used to describe incarcerated people, their life experience, behaviours, health risk factors, and medical conditions can therefore play an important role in supporting or undermining their health, wellbeing, and access to health information and services. However, terminology used to describe people affected by the criminal justice system in policies, programs, and research publications is often derogatory, stigmatizing, biased, and dehumanizing (e.g., criminal, prisoner, felon, offender, drug addict).

The use of respectful and person-centred language (also called 'person-first language') to describe individuals who are incarcerated, their characteristics, and experiences is fundamental to improving access to medication and services and minimizing discrimination [10]. Stigma-free language can positively influence media narratives, public opinion, and, above all, ensure that policy changes are inclusive of this priority population. The medical disciplines promote person-centred care that is culturally-sensitive and respectful of the ethical principles of autonomy, benevolence, and non-malevolence, which underpins quality of healthcare [11]. Respectful language is an integral part of this person-centred approach.

The World Health Organization (WHO) recommends in its 2013 style guide that language must not discriminate against, stereotype, or demean people on the basis of their age, physical or intellectual impairments, ethnicity, gender, sex or sexual orientation, although it does not address specifically problematic terminology used to describe people involved in the criminal justice system [12]. Despite these recommendations, the WHO landmark publication Prison and Health (2014) still uses language emphasizing imprisonment or criminality to describe incarcerated people (prisoner, inmate, offender) [13]. The Lancet series published in 2016 on HIV and related infections in prisoners widely used the term prisoner in its articles [14-18]. While the series title is crisp and effective in drawing attention to this major public health challenge, it is easy to associate the title with images of prisoners infected with HIV and other infections and posing a threat to society. Although people incarcerated living with HIV and other infections would be a mouthful alternative, it has the important merit of being person-centred with the aim of reducing stigma.

Efforts to promote a humanizing language have been undertaken in several contexts. These include sex and gender, sexuality, HIV [19], mental health [20], tuberculosis [21], and the use of psychoactive substances and controlled medicines [22]. The need to use humane language to describe individuals involved in the criminal justice system has recently gained momentum as evidenced by a ground-breaking policy document issued by the Scottish government in 2016 [23], followed by a letter to the editor in 2017 [24] and a commentary in 2018 [25] in peer-reviewed journals. Our paper extends this work and proposes four principles on the use of language to guide the way we speak, research, write, and communicate with and about the people affected by the criminal justice system. We highlight examples of stigmatizing and dehumanizing language and specific health conditions experienced by incarcerated people, before recommending alternative terminology that is person-centred, accurate, non-biased, respectful, and stigma-free.

\section{Guiding principles}

Engage people and respect their preferences

Table 1 compiles a list of commonly used terms to describe people involved in the criminal justice system and examples of health conditions and situations that can fuel negative stereotypes. We list problematic terms to be avoided and propose preferred wording. Policymakers, researchers, program managers, healthcare providers, criminal justice professionals, and custodial service commissioners should engage people who are currently or formerly incarcerated such as two contributors to this article (SC, CG) and one of the co-authors $(\mathrm{PB})$, respectively - and ask them about the language they prefer using to identify themselves. The Marshall Project in the USA [26] and User Voice in the UK [27] are examples of meaningful engagement with people involved in the criminal justice system. As terminology requires adaptation in local languages and cultures, each linguistic and professional community should be engaged in discussing and contextualizing these terms so that they are acceptable in the circumstances they are to be used.

\section{Use stigma-free and accurate language}

People experiencing incarceration are family and community members, friends, students, teachers, or coworkers. Indeed, as stated by UNAIDS in 1996 at the United Nations Commission on Human Rights, 'Prisoners are the community. They come from the community, they return to it. Protection of prisoners is protection of our communities.' However, people leaving imprisonment often face daunting barriers to reintegrate into their community and exercise their rights to housing, employment, health insurance coverage, education, voting or parenting, among others. Enabling them to re-enter society and preventing recidivism are primary objectives of detention. Terms that devalue, exclude, discriminate, stereotype, objectify, dehumanize, and reinforce a 'criminal self-image', such as offender, criminal, felon, prisoner, convict, should be avoided. Inmate should not be used as it is 
Table 1 Examples of terminology to avoid (in alphabetical order), problems related to its use, and preferred wording to describe people who are incarcerated

\begin{tabular}{|c|c|c|}
\hline Terminology to avoid & Problems & Preferred wording \\
\hline Abuse; misuse & $\begin{array}{l}\text { Judgmental; negates the fact that substance } \\
\text { use disorders are a medical condition [22]; } \\
\text { not conducive to fostering the trust and } \\
\text { respect required when engaging with people } \\
\text { who use psychoactive substances [19] }\end{array}$ & $\begin{array}{l}\text { (Heavy) substance use; substance use disorder } \\
\text { (Diagnostic and Statistical Manual of Mental } \\
\text { Disorders - DSM-5); dependence syndrome } \\
\text { (International Classification of Diseases - ICD-10) }\end{array}$ \\
\hline Body-packer; drug mule; drug smuggler & Not person-centred language, judgmental & $\begin{array}{l}\text { Person with body-packing, or with internal } \\
\text { concealment of psychoactive substance [36] }\end{array}$ \\
\hline Body-stuffer & Not person-centred language, judgmental & $\begin{array}{l}\text { Person diagnosed with acute ingestion of } \\
\text { psychoactive substance [36] }\end{array}$ \\
\hline $\begin{array}{l}\text { Correctional; offender; penitentiary; } \\
\text { prison health services }\end{array}$ & Reinforces stereotypes, moralistic, ambiguous. & $\begin{array}{l}\text { Health services in detention settings; healthcare } \\
\text { in prison }\end{array}$ \\
\hline $\begin{array}{l}\text { Crazy; mental; insane; psycho; mentally ill; } \\
\text { emotionally disturbed; demented }\end{array}$ & Not person-centred language, judgmental & $\begin{array}{l}\text { Person living with a mental health condition; } \\
\text { person living with dementia }\end{array}$ \\
\hline Dungeon; hole & Derogatory, inaccurate, reinforces self-stigma & Solitary confinement \\
\hline Drug user; abuser; addict; junkie; dependent & Not person-centred language, judgmental & $\begin{array}{l}\text { Person with a substance use disorder; person } \\
\text { with dependence syndrome; person who uses } \\
\text { psychoactive substances }\end{array}$ \\
\hline $\begin{array}{l}\text { Ex-prisoner; ex-offender; ex-inmate; } \\
\text { ex-felon; ex-con; criminal; thug; } \\
\text { post-carceral }\end{array}$ & Not person-centred language, judgmental & $\begin{array}{l}\text { Person who was in contact with, involved in, } \\
\text { interacted with or experienced the criminal } \\
\text { justice system; person with convictions; person } \\
\text { who was formerly incarcerated }\end{array}$ \\
\hline High(er)-risk group & $\begin{array}{l}\text { Implies that the risk is contained within the } \\
\text { group; can increase stigma and discrimination } \\
\text { against the designated groups; membership } \\
\text { of groups does not place individuals at risk, } \\
\text { behaviours may [19] }\end{array}$ & $\begin{array}{l}\text { Key populations; priority population; high-risk } \\
\text { behaviour (e.g., sharing needles, condomless sex) }\end{array}$ \\
\hline Hunger striker & Not person-centred language, judgmental & Person on hunger strike \\
\hline $\begin{array}{l}\text { Illegal immigrant; illegal; unlawful } \\
\text { non-citizen; visa overstayer; } \\
\text { undocumented alien }\end{array}$ & Not person-centred language, judgmental & Person who lacks resident documentation \\
\hline Prisoner; inmate; felon; offender & Not person-centred language, judgmental & $\begin{array}{l}\text { Person who is incarcerated; person who experience } \\
\text { incarceration; person in detention/jail/prison; person } \\
\text { living in detention/jail/prison; person involved in, or } \\
\text { experiencing the criminal justice system }\end{array}$ \\
\hline Prisoner-patient & $\begin{array}{l}\text { Health staff care for patients, irrespective } \\
\text { of their status }\end{array}$ & Patient; person in treatment \\
\hline Prostitute or prostitution & $\begin{array}{l}\text { Not person-centred language, } \\
\text { judgmental [12] }\end{array}$ & $\begin{array}{l}\text { Person involved in sex work, or in sale or trade of } \\
\text { sexual services; sex worker }\end{array}$ \\
\hline Probationer; parolee & Not person-centred language, judgmental & Person on parole; person on probation \\
\hline $\begin{array}{l}\text { Substitution therapy or opioid } \\
\text { substitution therapy (OST) }\end{array}$ & $\begin{array}{l}\text { Misleading: gives the impression to } \\
\text { politicians, civil servants, and other lay } \\
\text { people that this therapy is replacing 'street } \\
\text { drugs' with 'state drugs'; and therefore, } \\
\text { this language counteracts availability } \\
\text { of therapy [22] }\end{array}$ & $\begin{array}{l}\text { Opioid agonist therapy (OAT); opioid agonist } \\
\text { therapy for the treatment of substance use } \\
\text { disorder; treatment [37] }\end{array}$ \\
\hline
\end{tabular}

ambiguous and refers to people living in any institution, including psychiatric hospitals [28].

The language we use to conceptualize and talk about incarcerated people and their characteristics reflects our personal views and understanding, or, too often, our biases (conscious or unconscious) and lack of understanding. It also helps shape our own and others' attitudes about people involved in the criminal justice system and the way we grant or limit (at times unknowingly) their access to services. Therefore, defining people by the crime for which they were convicted (e.g., drug dealer, murderer, rapist, sex offender, paedophile) or by their legal status (e.g., illegal immigrant), and using moralistic language regarding substance use (e.g., drug abuser) or work (e.g., prostitute) is not helpful in supporting respectful interaction.

Use of the term correctional, which has been common since the 1950s in North America to describe the criminal justice system and related institutions (e.g., correctional 
health services), should be re-examined: it is linked to the sombre history of forced correctional labour camps [29], can be construed as moralistic, and is underpinned by the concept of 'deviant' behaviours to be corrected (while many people instead require treatment and care, rather than 'behaviour correction' such as for substance use disorders or mental health conditions). We should also reconsider the use of the term penitentiary (from penitens in Latin, meaning regretting or repenting) due to the strong religious connotation: 'God's forgiveness' requires penitence and implies a sad and humble regret for one's sins or wrongdoing.

Double denomination, such as prisoner-patient, should not be used in health service guidelines or by healthcare professionals [30]. The term puts the detention status of people before their needs for medical attention. It emphasizes the dual loyalty confusion for health professionals: one that often obfuscates the provider's primary relationship (towards healthcare principles and ethics or towards the prison authorities) [31]. Healthcare providers, even if they are directly employed by prison authorities, must first attend to their patients as patients and act independently of prison or judicial authorities [32].

\section{Prioritize the individual}

Incarceration is often perceived as the worst experience of one's life. However, individuals in detention are not defined only by the experience. Even when restricted in their freedom of movement, people must be given the resources to keep living with dignity and respect. Healthcare professionals have learned not to label patients by their medical diagnosis (e.g., we use person with body packing or with internal concealment of psychoactive substance instead of body packer; person on hunger strike instead of hunger striker). Likewise, we recommend placing individuals at the centre, and their characteristics or medical conditions second in the description. Therefore, the use of person-centred language should be preferred to describe what people have or the circumstances in which they live, which in the end should not define who they are and how we treat them. For instance: person who is incarcerated or living in detention/prison/jail (instead of prisoner) or person living with HIV (instead of HIV-infected patient) emphasize the fact that individuals are not powerless and can continue to live with dignity despite their environment or condition; person formally incarcerated, person with convictions (instead of ex-con) factually describes people in a specific phase of their life.

\section{Cultivate self-awareness}

Professionals working with people who are incarcerated should be conscious of the language they use as it can convey powerful images and meanings. They should favour in their clinical practice, policy, and research the use of humane and constructive language that promotes respect, dignity, understanding, and positive outlooks, and should encourage colleagues, friends, and their community to do so. Likewise, recognizing their influence in positively shaping public opinion, we call upon scientific journals, the media, governments, national and international organizations, including the legal community, to strive to adopt language that respects the dignity of people involved in the criminal justice system. While some people may not use preferred terminology, it is important for professionals of all sectors to develop cultural humility and self-reflection [33], be mindful, and refrain from repeating negative terms that discriminate, devalue, and perpetuate harmful stereotypes and power imbalances. Values clarification workshops for healthcare (and non-healthcare) professionals and researchers working with people involved in the criminal justice system could be transformative in clarifying values and changing attitudes to improve interactions with others [34], as may interventions to transform self-stigma and build the coping skills of individuals incarcerated, their families, and children [35]. Such interventions have the power of challenging prejudices, stigma, and self-stigma by increasing an individual's awareness of values that may have a bearing on decisions and actions in their lives. Values clarification can therefore enhance our understanding of the complex sociocultural, psychological, and behavioral determinants of incarceration, redirect personal values, and address potential barriers to change the use of inappropriate language (e.g., through supportive supervision of staff working with incarcerated people). These actions can work to assist professionals to prioritize the use of terminology that adheres to our professional mandate: caring for people and supporting them in their journey of recovery and reintegration into society. Our use of language must promote such processes.

\section{Conclusion}

Respectful language is a cornerstone of reducing harm and suffering. Healthcare professionals, researchers, and policy makers working with people involved in the criminal justice system can be guided by key principles that foster constructive and humanizing language: engage people and respect their preferences, use stigma-free and accurate language, prioritize individuals over their characteristics, and cultivate self-awareness. Problematic terms must be avoided because they do not convey respect. However, the preferred wording we propose is far from being universal: it requires contextualization to local language and socio-cultural environment. Tension can also arise when trying to use respectful language and at the same time be concise and efficient, especially in policy documents, guidelines, and scientific publications. This requires a pragmatic approach, but one that should 
not sacrifice the promotion and use of stigma-free and more accurate language. We call upon all professionals to be self-reflective and mindful that names can hurt and that appropriate language to describe people experiencing incarceration can reduce harm and enhance health and wellbeing. We must therefore strive to develop a suitable vocabulary and communication style that embody respect, dignity, and humanity for all people - free or incarcerated.

\section{Abbreviation}

WHO: World Health Organization

\section{Acknowledgements}

We are grateful to Sunil Chatterjee and Kristoffel Grechenig who offered a detailed review of the initial draft and insightful comments and contributions to enrich the article from the perspective of individuals involved in the criminal justice system.

\section{Funding}

Not applicable.

\section{Availability of data and materials}

Not applicable.

\section{Authors' contributions}

$\mathrm{NTT}, \mathrm{SB}$, and HW conceptualized the paper; NTT wrote the first draft with critical inputs from $\mathrm{SB}, \mathrm{AD}, \mathrm{BW}, \mathrm{PB}, \mathrm{OS}, \mathrm{WS}, \mathrm{LG}$, and $\mathrm{HW}$. In addition, ÉO provided nuanced analysis on terminology use. All authors contributed toward drafting and revising the paper. All read and approved the final version and agreed to be accountable for all aspects of the work.

\section{Authors' information}

$N T T, E ́ O, B W, L G$, and HW are physicians, researchers, public health specialists, and academics with expertise in health in prison; SB is an academic (psychology and statistics background) with expertise in public health and addiction; $A D$ is a public health social scientist with expertise in maternal and reproductive health delivery to priority populations; $\mathrm{PB}$ is a researcher, academic, and a person formally involved in the criminal justice system; OS, a psychiatrist, and WS, a pharmacist, are advocates for neutral, precise, and respectful language related to the use of controlled medicines. The article draws from the authors' experiences, discussions, and published work focused on people-centred language and healthcare access for people who are involved in the criminal justice system.

\section{Ethics approval and consent to participate}

Not applicable.

\section{Consent for publication}

Not applicable.

\section{Competing interests}

The authors declare that they have no competing interests.

\section{Publisher's Note}

Springer Nature remains neutral with regard to jurisdictional claims in published maps and institutional affiliations.

\footnotetext{
Author details

'Division of Prison Health, Geneva University Hospitals and University of Geneva, Ch. du Petit-Bel-Air 2, CH-1225 Chêne-Bourg, Switzerland. ${ }^{2}$ Australian Centre for Public and Population Health Research, Faculty of Health, University of Technology, PO Box 123, Sydney, NSW 2007, Australia. ${ }^{3}$ Public Health England \& UK Collaborating Centre, WHO Health in Prisons Programme, Premier House, 60 Caversham Road, Reading RG1 7EB, UK. ${ }^{4}$ Division of Geriatrics, Criminal Justice \& Health Program, University of California in San Francisco, 3333 California Street, San Francisco, CA 94118, USA. ${ }^{5}$ Department of Psychiatry, School of Medicine \& Dentistry, University of Rochester, 300 Crittenden Boulevard, Rochester, NY 14642, USA. ${ }^{6}$ Psychiatry
}

Department, Centre hospitalier universitaire de Lausanne, Av. Recordon 40, 1004 Lausanne, Switzerland. Willem Scholten Consultancy, Wielsekade 64, 3411 AD Lopik, The Netherlands.

Received: 30 August 2018 Accepted: 31 October 2018

Published online: 16 November 2018

\section{References}

1. Walmsley R. World prison brief. Walmsley R. World prison population list. 11th ed. London: International Centre for Prison Studies; 2016. http:// prisonstudies.org/sites/default/files/resources/downloads/world_prison_ population_list_11th_edition_0.pdf. Accessed 11 Aug 2016.

2. Fazel S, Baillargeon J. The health of prisoners. Lancet. 2011;377:956-65.

3. Pogorzelski W, Wolff N, Pan K-Y, Blitz CL. Behavioral health problems, exoffender reentry policies, and the "second chance act". Am J Public Health. 2005;95:1718-24.

4. Rich JD, Allen SA, Williams BA. The need for higher standards in correctional healthcare to improve public health. J Gen Intern Med. 2015;30:503-7.

5. Stürup-Toft S, O'Moore EJ, Plugge EH. Looking behind the bars: emerging health issues for people in prison. Br Med Bull. 2018;125(1):15-23.

6. Winnick TA, Bodkin M. Anticipated stigma and stigma management among those to be labeled "ex-con". Deviant Behav. 2008;29:295-333.

7. Ellis E. Words Matter: Another Look at the Question of Language. Brooklyn: Center for New Leadership on Urban Solution; 2013. https://ezwaters.wordpress.com/ 2017/12/17/words-matter-another-look-at-the-question-of-language-by-eddieellis-president-center-for-nuleadership-on-urban-solutions/. Accessed 1 May 2018.

8. Jacobson J, Heard C, Fair H. Prison: evidence of its use and over-use from around the world. In: Book Prison: evidence of its use and over-use from around the world (Editor ed.^eds.). City: Institute for Criminal Policy Research; 2017. p. 48.

9. Schnittker J, John A. Enduring stigma: the long-term effects of incarceration on health. J Health Soc Behav. 2007;48:115-30.

10. Pascoe EA, Smart Richman L. Perceived discrimination and health: a metaanalytic review. Psychol Bull. 2009;135:531.

11. Lee Y-Y, Lin JL. Do patient autonomy preferences matter? Linking patientcentered care to patient-physician relationships and health outcomes. Soc Sci Med. 2010;71:1811-8.

12. World Health Organization. WHO style guide. Geneva: World Health Organization; 2013.

13. World Health Organization. Prisons and health. Geneva: World Health Organization; 2014.

14. Dolan K, Wirtz AL, Moazen B, Ndeffo-mbah M, Galvani A, Kinner SA, Courtney R, McKee M, Amon JJ, Maher L. Global burden of HIV, viral hepatitis, and tuberculosis in prisoners and detainees. Lancet. 2016:388:1089-102.

15. Kamarulzaman A, Reid SE, Schwitters A, Wiessing L, El-Bassel N, Dolan K, Moazen B, Wirtz AL, Verster A, Altice FL. Prevention of transmission of HIV, hepatitis $B$ virus, hepatitis $C$ virus, and tuberculosis in prisoners. Lancet. 2016:388:1115-26.

16. Rubenstein $L S$, Amon JJ, McLemore M, Eba P, Dolan K, Lines R, Beyrer C. HIV, prisoners, and human rights. Lancet. 2016:388:1202-14.

17. Telisinghe L, Charalambous S, Topp SM, Herce ME, Hoffmann CJ, Barron P, Schouten EJ, Jahn A, Zachariah R, Harries AD. HIV and tuberculosis in prisons in sub-Saharan Africa. Lancet. 2016;388:1215-27.

18. Altice FL, Azbel L, Stone J, Brooks-Pollock E, Smyrnov P, Dvoriak S, Taxman FS, El-Bassel N, Martin NK, Booth R. The perfect storm: incarceration and the highrisk environment perpetuating transmission of HIV, hepatitis $C$ virus, and tuberculosis in Eastern Europe and Central Asia. Lancet. 2016;388:1228-48.

19. UNAIDS. UNAIDS terminology guidelines. Geneva: UNAIDS; 2015.

20. Jensen ME, Pease EA, Lambert K, Hickman DR, Robinson O, McCoy KT, Barut JK, Musker KM, Olive D, Noll C. Championing person-first language: a call to psychiatric mental health nurses. J Am Psychiatr Nurses Assoc. 2013;19:146-51.

21. Zachariah R, Harries A, Srinath S, Ram S, Viney K, Singogo E, Lal P, MendozaTicona A, Sreenivas A, Aung N. Language in tuberculosis services: can we change to patient-centred terminology and stop the paradigm of blaming the patients?[Perspectives]. Int J Tuberc Lung Dis. 2012;16:714-7.

22. Scholten W, Simon O, Maremmani I, Wells C, Kelly J, Hämmig R, Radbruch L. Access to treatment with controlled medicines rationale and recommendations for neutral, precise, and respectful language. Public Health. 2017;153:147-53.

23. The Scottish Government. National Strategy for Community Justice. Edinburgh: The Scottish Government; 2016. http://www.gov.scot/Resource/ 0051/00510489.pdf. Accessed 9 May 2018. 
24. Goshin LS. Humane language for people in the criminal justice system. JAMA. 2017;318:2258-9.

25. Bedell PS, Spaulding AC, So M, Sarrett JC. The names have been changed to protect the... Humanity: person-first language in correctional health epidemiology. Am J Epidemiol. 2018;187(6):1140-2.

26. Inmate. Prisoner. Other. Discussed. What to call incarcerated people: your feedback. https://www.themarshallproject.org/2015/04/03/inmate-prisonerother-discussed. Accessed 1 May 2018.

27. User Voice - Listening to the Stories and Experiences of Service Users. http://www.uservoice.org/. Accessed 1 May 2018.

28. English Oxford Living Dictionary. https://en.oxforddictionaries.com/ definition/inmate. Accessed 1 May 2018.

29. Daria T. Use of correctional and labour measures on the inmates of the Solovetsky camp in the 1920s and 1930s. Arctic Rev. 2012;3(2):186-99.

30. HM Inspectorate of Prisons for England and Wales. Patient or prisoner? A new strategy for health care in prisons. London: Home Office London; 1996.

31. Pont J, Stöver H, Wolff H. Dual loyalty in prison health care. Am J Public Health. 2012;102:475-80.

32. Pont J, Enggist S, Stöver H, Williams B, Greifinger R, Wolff H. Prison health care governance: guaranteeing clinical Independence. Am J Public Health. 2018;108:472-6.

33. Yeager KA, Bauer-Wu S. Cultural humility: essential foundation for clinical researchers. Appl Nurs Res. 2013;26:251-6.

34. Molleman T, Leeuw FL. The influence of prison staff on inmate conditions: a multilevel approach to staff and inmate surveys. Eur J Crim Policy Res. 2012; 18:217-33.

35. Dawson A, Jackson D, Nyamathi A. Children of incarcerated parents: insights to addressing a growing public health concern in Australia. Child Youth Serv Rev. 2012;34:2433-41.

36. Traub SJ, Hoffman RS, Nelson LS. Body packing - the internal concealment of illicit drugs. N Engl J Med. 2003;349:2519-26.

37. Friedmann PD, Schwartz RP. Just call it "treatment". Addict Sci Clin Pract. 2012;7:10

Ready to submit your research? Choose BMC and benefit from:

- fast, convenient online submission

- thorough peer review by experienced researchers in your field

- rapid publication on acceptance

- support for research data, including large and complex data types

- gold Open Access which fosters wider collaboration and increased citations

- maximum visibility for your research: over $100 \mathrm{M}$ website views per year

At $\mathrm{BMC}$, research is always in progress.

Learn more biomedcentral.com/submissions 